\title{
Estimation of Design Parameters
}

for Cellular WCDMA Network

\author{
S. A. Mawjoud \\ Electrical Dept. - College of Engerneering - Mosul University
}

\begin{abstract}
The estimation of design parameters for WCDMA network which support different data rate (Multimedia) services is an essential step in network planning. The estimated parameters includes: Cell coverage range using path loss propagation model, average and maximum path loss, throughput, capacity $/ \mathrm{km}^{2}$, number of users per cells blocking capacity, tracking efficiency. The parameters are computed for different data rates.
\end{abstract}

Key words: WCDMA, noise rise, load factors.

تقدير معالم التصميم لثبكة اتصالات خلوية نوع WCDMA

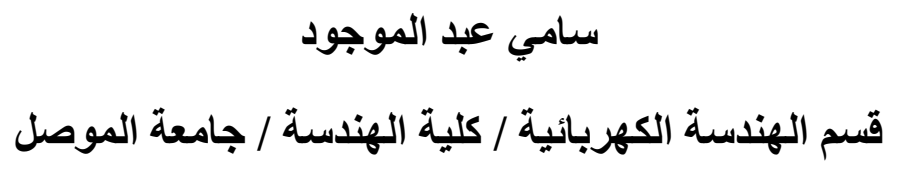




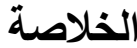

إن تقدير معالم التصميم لنظم WCDM هي من الأولويات لتصميم شبكة قادرة على نقل بيانات مختلفة المعدل تمثل الصوت الصن أو الصورة.

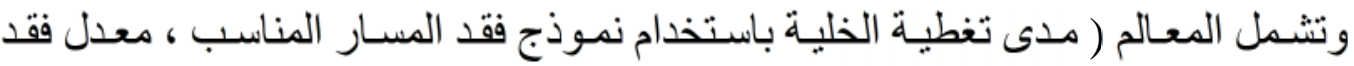
المسار و أقصى فقد للمسار ، الإخر اج ، السعة لكل كيلومتر مربع ، عدد المستخدمين في الخلية ، سعة الصد ، وكفاءة النقل الرئيسي البعيد.

\section{Introduction:}

Wideband Code Division Multiple Access (WCDMA) is the third generation $(3 \mathrm{G})$ mobile cellular communication system. 
The attractive features of WCDMA is the very high data rate (up to $2 \mathrm{Mbps}$ ) to support multimedia services (voice, video, internet) and the internetworking with Globate System For Mobile Communication (GSM) and General Packet Radio Service (GPRS). In addition WCDMA has certain performance benefits, such as increased multipath diversity [1]. In network planning, parameters estimation are the key factors in the network planning phase (e.g., Large area coverage, highest capacity per $\mathrm{km}^{2}$, soft capacity (Enlarge capacity), tracking efficiency and blocking probability.

\section{The Link Budget:}

The link budget of WCDMA (3G) have some specific parameters that are not used in GSM (2G). The most important are:

- Interference-margin: is needed in the link budget because of the loading of the cell, the load factor affects the coverage, the more loading is allowed in the system the large is the interference margin needed in the uplink and the smaller is the coverage area. For coverage limited cases, smaller interference margin is used (1-3 dB) corresponds to $20-50 \%$ loading. While in a capacity limited cases a larger interference margin is used.

- Fast fading margin (= power control headroom): Some headroom is needed in the mobile station (MS) transmission power for maintaining closed loop fast power control to effectively compensate the fast fading [1]. Typical values of the fast fading margin are $2-5 \mathrm{~dB}$ for slow moving mobiles.

- Soft handover gain: Handover (soft or hard) gives gain against slow fading (Log normal fading) by reducing the required Log-normal margin. Since slow fading is partly uncorrelated between the Base Stations (BSs), by making a handover, the mobile can select a better BS. Soft handover gives an additional macro diversity against fast fading by reducing the signal power to noise power $\left(\mathrm{E}_{\mathrm{b}} / \mathrm{N}_{\mathrm{o}}\right)$ relative to a single radio link. The total soft handover gain is assumed to be between $2-3 \mathrm{~dB}$ in the example below including the gain against slow and fast fading.

Three examples of link budgets are given for typical universal mobile. Telecommunication Services (UMTS) which implements WCDMA.

- 12.2 kbps voice service using adaptive multirate (AMR) speech codec.

- 144 kbps real time data. 
- 384 kbps non-real time data.

In the urban macro-cellular environment at the planned uplink a noise rise of $3 \mathrm{~dB}$ and interference margin of $3 \mathrm{~dB}$ is reserved for the uplink noise rise. The assumptions are in the link budget [2] for the receivers and the transmitters are shown in tables 1 and 2.

Table 1. Assumptions for the Mobile Station [1].

\begin{tabular}{|l|l|l|}
\cline { 2 - 3 } \multicolumn{1}{l|}{} & $\begin{array}{l}\text { Speech } \\
\text { terminal }\end{array}$ & \multicolumn{2}{l|}{ Data terminal } \\
\hline $\begin{array}{l}\text { Maximum transmission } \\
\text { power }\end{array}$ & $\begin{array}{l}21 \mathrm{dBm} \quad(0.125 \\
\mathrm{W})\end{array}$ & $\begin{array}{l}24 \mathrm{dBm} \quad(0.25 \\
\mathrm{W})\end{array}$ \\
\hline Antenna gain & $0 \mathrm{dBi}$ & $2 \mathrm{dBi}$ \\
\hline Body loss & $3 \mathrm{~dB}$ & $0 \mathrm{~dB}$ \\
\hline
\end{tabular}

Table 2. Assumptions for the Base Station [1].

\begin{tabular}{|l|l|}
\hline Noise figure & $5 \mathrm{~dB}$ \\
\hline Antenna gain & $\begin{array}{l}18 \mathrm{~dB} \quad(3 \text { sector Base } \\
\text { Station })\end{array}$ \\
\hline & $\begin{array}{l}\text { Speech } 5 \mathrm{~dB} \\
144 \text { kbps real time data } 1.5 \\
\mathrm{~dB} \\
\mathrm{E}_{\mathrm{b}} / \mathrm{N}_{\mathrm{o}}\end{array}$ \\
& $\begin{array}{l}384 \mathrm{kbps} \text { non time data } 1 \\
\mathrm{~dB}\end{array}$ \\
\hline Cable loss & $2 \mathrm{~dB}$ \\
\hline
\end{tabular}




\section{Cell Coverage Range:}

Once the maximum allowed propagation loss in the cell is known, then applying propagation model for cell range estimation. The propagation model is chosen so that it is optionally describes the propagation condition in the area. The restrictions on the model are the carrier frequency used, BS to MS distance, BS and MS antenna heights. For urban and suburban macro-cellular system Okumura-Hata propagation model is used [3][4].

$$
\begin{aligned}
L_{P U A}= & A+B \log _{10} f-13.82 \log _{10} h_{b}-a\left(h_{m}\right) \\
& +\left(C-6.55 \log _{10} h_{b}\right) \log _{10} R(d B)
\end{aligned}
$$

Where:

$\mathrm{L}_{\mathrm{PUA}}:$ is the path loss in urban area $(\mathrm{dB})$.

$\mathrm{f}: \quad$ is the carrier frequency $(\mathrm{MHz})$.

$h_{b}: \quad$ is the base station antenna height $(m)$.

$\mathrm{h}_{\mathrm{m}}: \quad$ is the mobile station antenna height $(\mathrm{m})$.

$\mathrm{A}=46.3 \mathrm{~dB}$.

$B=33.9 \mathrm{~dB}$.

$\mathrm{C}=44.9 \mathrm{~dB}$.

$\mathrm{R}=\quad$ the cell range radius $(\mathrm{km})$.

a $\left(h_{m}\right)$ is a correction factor for the mobile antenna height $\cong 0$.

For urban macrocell, $\mathrm{f}=1950 \mathrm{MHz}, \mathrm{h}_{\mathrm{b}}=30 \mathrm{~m}, \mathrm{~h}_{\mathrm{m}}=1.5 \mathrm{~m}$, noise rise $=3 \mathrm{~dB}$ (corresponds to $50 \%$ loading, interference margin of $3 \mathrm{~dB}$ for the uplink.

$$
\therefore L_{P U A}=137.4+35.2 \log _{10} R
$$

The path loss for suburban area is by adding a correction factor of 8 $\mathrm{dB}$ to the $\mathrm{L}_{\mathrm{PUA}}[1]$. 
For the allowed path loss [1] in the case of voice and data, the cell coverage range is calculated and the results are shown in table 3.

Table 3. Allowed propagation loss and calculated cell range in urban and suburban macrocell for voice and data.

\begin{tabular}{|l|l|l|l|}
\hline \multirow{2}{*}{ Area } & $\begin{array}{l}\text { Information } \\
\text { (kbps) }\end{array}$ & $\begin{array}{l}\text { Allowed path } \\
\text { loss (dB) }\end{array}$ & $\begin{array}{l}\text { Cell } \\
\text { range } \\
\mathbf{( k m )}\end{array}$ \\
\hline \multirow{2}{*}{ Urban } & Voice 12.2 & 141.9 & 1.34 \\
\cline { 2 - 4 } & Data 144 & 133.8 & 0.79 \\
\hline \multirow{2}{*}{ Suburban } & Voice 12.2 & 141.9 & 2.27 \\
\cline { 2 - 4 } & Data 144 & 133.8 & 1.33 \\
\hline
\end{tabular}

\section{Load Factors [5][1]:}

\subsection{Uplink Load Factor:}

The theoretical spectral efficiency of a WCDMA can be calculated using equation (3) below:

$$
\eta_{U L}=(1+i) \cdot \sum_{j=1}^{N} \frac{1}{1+\frac{W}{\left(E_{b} / N_{o}\right)_{j} \cdot R_{j} \cdot v_{j}}}
$$

Where:

$\eta_{\mathrm{UL}}: \quad$ is the load factor for the uplink.

$E_{b} / N_{o}$ : is the signal energy per bit divided by noise spectral density that is required to meet a predefined block error rate.

$\mathrm{N}$ : number of users per cell.

W: CDMA chip rate (chip per sec.). 
$\mathrm{R}_{\mathrm{j}}$ : $\quad$ bit rate of user $\mathrm{j}$.

$v_{\mathrm{j}}$ : $\quad$ activity factor for uses $\mathrm{j}$ and is 0.67 for voice and for data.

The $\mathrm{i}$ factor depends on propagation environment, overlapping cell areas, the number of sector in the base station, the traffic intensity and its distribution, as well as on the distance to the serving and interfering cells [6].

For voice service network, where all users in the cell have low bit rate $(\mathrm{R})$ i.e.

$$
\frac{\mathrm{W}}{\mathrm{E}_{\mathrm{D}} / \mathrm{N}_{\mathrm{o}} \cdot \mathrm{R} \cdot \mathrm{v}}>>1
$$

and hence equation 3 is simplified to:

$$
\eta_{\mathrm{UL}}=\frac{\mathrm{E}_{\mathrm{b}} / \mathrm{N}_{\mathrm{o}}}{\mathrm{W} / \mathrm{R}} \cdot \mathrm{N} \cdot \mathrm{v} \cdot(1+\mathrm{i})
$$

\section{- Noise Rise:}

The noise rise is defined in [5] as:

$$
\begin{aligned}
& \text { Noise rise }=\frac{1}{1-\eta_{U L}} \\
& \text { Noise rise }=-10 \log _{10}\left(1-\eta_{U L}\right)
\end{aligned}
$$

The load equation (4) is used to make a semi-analytical prediction of the average capacity of WCDMA without going into system level simulation. Equation (6) can be used to predict cell capacity and noise rise. From equation (5) it can be seen that as $\eta_{\mathrm{UL}}$ becomes close to one, the corresponding noise rise approaches infinity and the system has reached its pole capacity.

For noise rise calculation, the value of $\mathrm{E}_{\mathrm{b}} / \mathrm{N}_{\mathrm{o}}$ is different for different data rate as given in table 4 . 
Table 4. $\mathbf{E}_{b} / \mathbf{N}_{0}$ for different Services [5].

\begin{tabular}{|l|l|l|l|l|}
\cline { 2 - 5 } \multicolumn{1}{c|}{} & Voice & \multicolumn{3}{l|}{ Data } \\
\multicolumn{1}{c|}{} & $12 \mathrm{kbps}$ & $64 \mathrm{kbps}$ & $144 \mathrm{kbps}$ & $328 \mathrm{kbps}$ \\
\hline $\mathrm{E}_{\mathrm{b}} / \mathrm{N}_{\mathrm{o}}$ & $5.1 \mathrm{~dB}$ & $1.7 \mathrm{~dB}$ & $0.9 \mathrm{~dB}$ & $1 \mathrm{~dB}$ \\
\hline
\end{tabular}

A sample of calculation: For speech, $\mathrm{E}_{\mathrm{b}} / \mathrm{N}_{\mathrm{o}}=5.1 \mathrm{~dB}, \mathrm{~W}=3.8 \mathrm{Mcps}$, $\mathrm{R}=12.2 \mathrm{kbps}, \mathrm{N}=$ number of users, $\mathrm{i}=0.65$ for voice, $\mathrm{V}=0.67$ for voice and 1 for data. Using equations (3) and (6) the results are shown in figure (1).
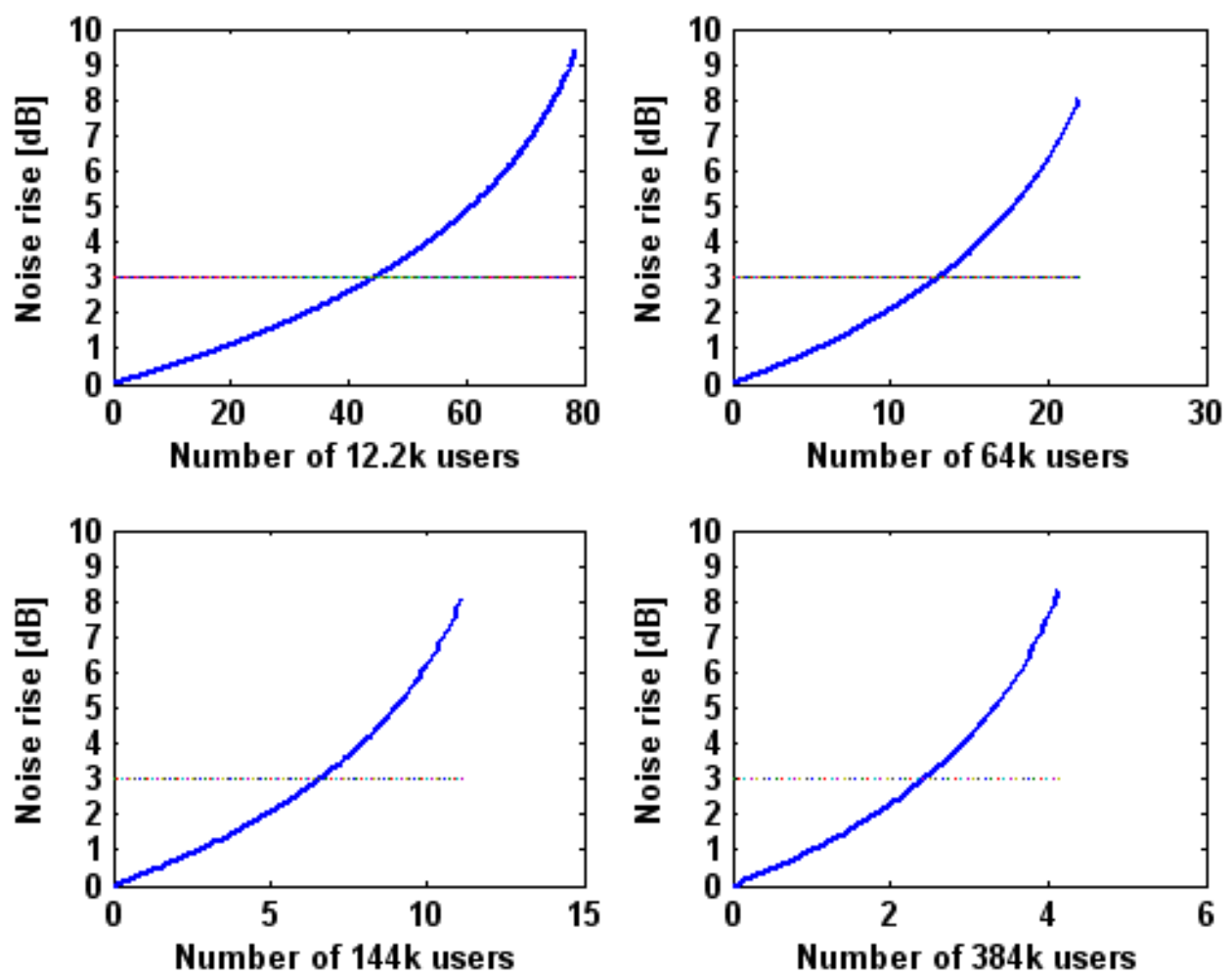

Figure (1) Noise rise versus number of users for different data rate 

Figure (1) shows the noise rise versus the number of users for different data rate. It can be seen for figure (1) that for constant noise rise value, the number of users decreases for higher bit rate.

- Throughput is defined as:

Throughput $=\mathrm{N} * \mathrm{R}$

Where, $\mathrm{N}$ is the number of users and $\mathrm{R}$ is the bit rate.

Figures (2-a) and (2-b) show the variation of noise rise with throughput for different interference level (i), for voice (12.2 kbps) and data $(64 \mathrm{kbps})$ which show that as interference increases the noise increases and system capacity decreases.

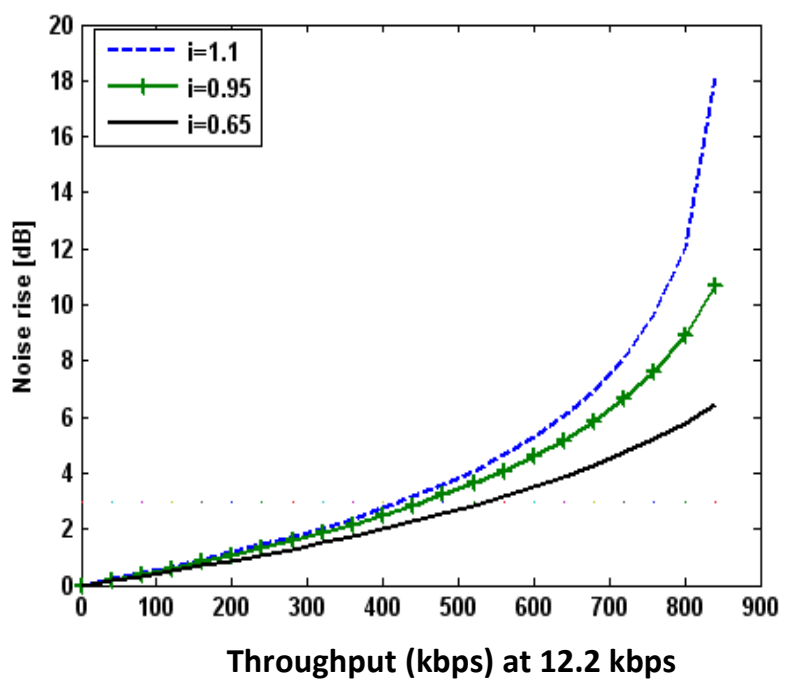

(a)

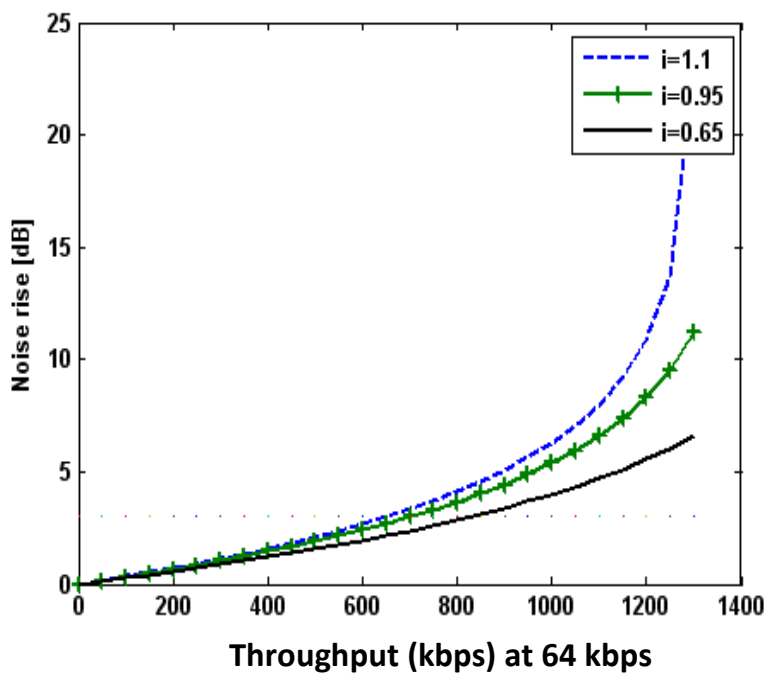

(b)

Figure (2): Throughput versus noise rise for (a) $12.2 \mathrm{kbps}$, (b) $64 \mathrm{kbps}$. 


\subsection{Downlink Load Factor:}

The downlink load factor $\left(\eta_{\mathrm{DL}}\right)$ can be defined similarly as for the uplink although the parameters are slightly different [1] [2] [5].

$$
\eta_{D L}=\sum_{j=1}^{N} v_{j} \cdot \frac{E_{b} / N_{o}}{W / R_{j}} \cdot\left[\left(1-\alpha_{j}\right)+i_{j}\right]
$$

Comparing equations (7) and (3), $\alpha_{j}$ is the most important new parameter which represents the orthogonality factor in the downlink, typical $\alpha_{j}$ is between 0.4 to 0.9 in multipath radio channel. In downlink the value of $i$ depends on the user location and therefore is different for each user $\mathrm{j}$. The load factor can be approximated by the average value across the cell.

$$
\bar{\eta}_{D L}=\sum_{j=1}^{N} v_{j} \cdot \frac{\left(E_{b} / N_{o}\right)_{j}}{W / R_{j}} \cdot[(1-\bar{\alpha})+\bar{i}]
$$

The minimum required transmission power between the base station transmitter and the mobile receiver is the average path loss $(\overline{\mathrm{L}})$ and the mobile receiver sensitively in the absences of multipath access interference. The effect of noise rise interference is then added

to the minimum power, and the total represents the transmission power required for the user at an average location in the cell. Therefore the total base station transmit power can be represented.

BS.Tx P $=\frac{N_{r f} \cdot W \cdot \bar{L} \cdot \sum_{j=1}^{N} v_{j} \frac{\left(\frac{E_{b}}{N_{o}}\right)_{j}}{W / R_{j}}}{1-\bar{\eta}_{D L}}$

Where:

BS. Tx p: is the highest transmit power of base station.

$\mathrm{N}_{\mathrm{rf}}$ is the noise spectral density of the mobile receiver front-end. 
$\mathrm{N}_{\mathrm{rf}}=\mathrm{KT}+\mathrm{NF}$

(11)

$$
N_{r f}=-174 d B m+N F
$$

Where:

$\mathrm{K}$ : Boltzman's constant $1.381 \times 10^{-23} \mathrm{~J} / \mathrm{K}$.

$\mathrm{T}$ : the temperature in Kelvin (assuming $\mathrm{T}=290^{\circ} \mathrm{k}$ ).

NF: the noise figure, typical range 5-9 [1].

$\overline{\mathrm{L}}$ : average path loss (minimum power level required by user).

\section{Sample of Calculations:}

- Assuming the required aggregate cell throughput in kbps.

- Using the load factor $\bar{\eta}_{\mathrm{DL}}$ from equation 9, then throughput is:

Throughput $=\mathrm{N} \times \mathrm{R} \times(1-\mathrm{BLER})$

Where:

$\mathrm{R}$ is the bit rate (bps).

BLER is the block error bit.

- Using equation 10, the average path loss $(\overline{\mathrm{L}})$ can be calculated.

- The maximum path loss is calculated by adding $6 \mathrm{~dB}$ from [6][1] which is the difference between maximum path loss and average path loss.

Table 5. Values in example calculation [1].

\begin{tabular}{|l|l|l|}
\hline Parameter & Voice & Data \\
\hline BS. Tx P & $20 \mathrm{~W}$ & $20 \mathrm{~W}$ \\
\hline NF & $7 \mathrm{~dB}$ & $7 \mathrm{~dB}$ \\
\hline
\end{tabular}




\begin{tabular}{|l|l|l|}
\hline $\mathrm{W}$ & 3.84 Mbps & 3.84 Mbps \\
\hline \multirow{2}{*}{$\mathrm{V}_{\mathrm{j}}$} & Down Link: 0.58 & \multirow{2}{*}{1} \\
\cline { 2 - 3 } & Uplink: 0.67 & \\
\hline $\mathrm{E}_{\mathrm{b}} / \mathrm{N}_{\mathrm{o}}$ & $7 \mathrm{~dB}$ & $5 \mathrm{~dB}$ \\
\hline $\mathrm{R}$ & $12.2 \mathrm{kbps}$ & $64 \mathrm{kbps}$ \\
\hline $\mathrm{I}$ & 0.65 & 0.65 \\
\hline BLER & $1 \%$ & $10 \%$ \\
\hline Maximum versus & $6 \mathrm{~dB}$ & $6 \mathrm{~dB}$ \\
average path loss & \multicolumn{2}{|l}{} \\
\hline
\end{tabular}

- The results are plotted as shown in figures 3 and 4.

Figure (3) is throughput versus maximum path loss, and figure (4) is for the number of users versus maximum path loss both are for data of $64 \mathrm{kbps}$. It can be noticed in both that the load affects the coverage but is not the same for UL and DL. In the DL the coverage depends in the downlink, since in the downlink the power $(20 \mathrm{~W})$ is shared between the downlink user, the less power per user. Therefore even with low load in the DL, the coverage decrease as the number of users (or throughput increases).
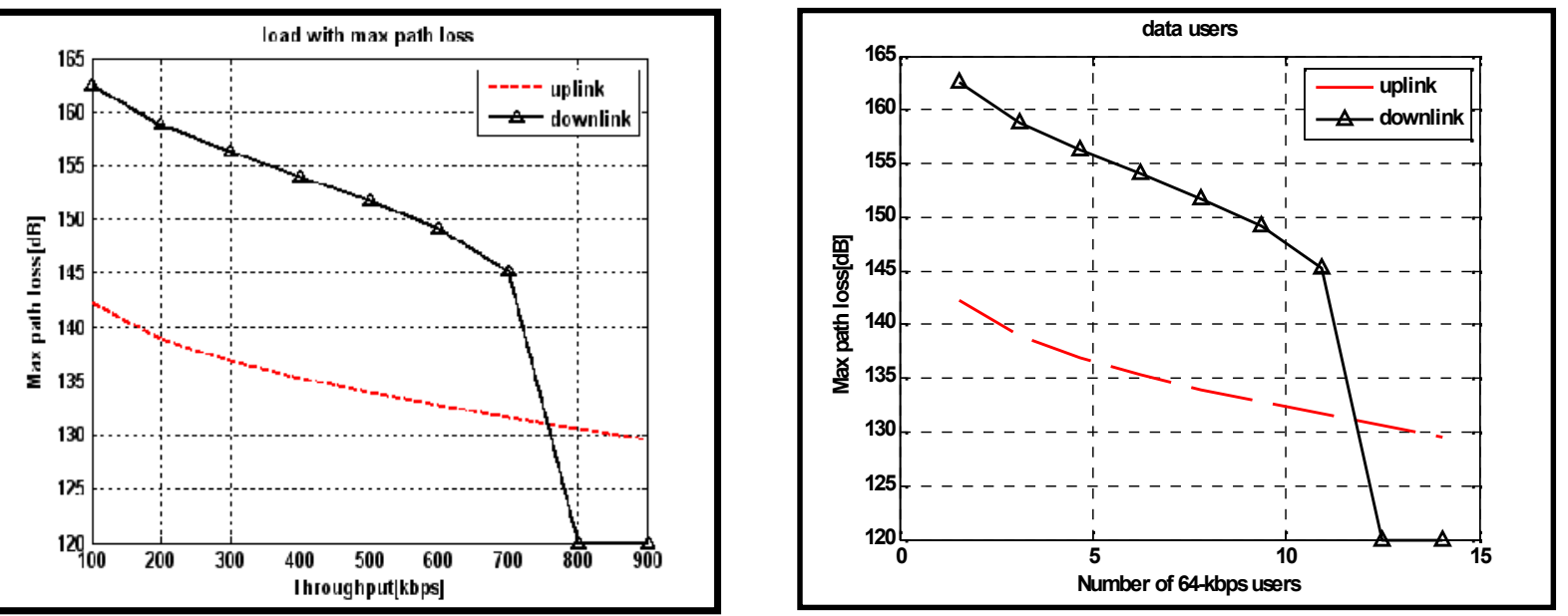

Figure (3) Variations of capacity (throughput)

and coverage (max path loss) for $64 \mathrm{kbps}$ in 
Figure (4) Variations of capacity and coverage (max path loss) for $64 \mathrm{kbps}$ in uplink and Noumlint

\section{Capacity Upgrade Paths:}

When the amount of traffic increases, the downlink capacity can be upgraded in a number of ways [1] [6].

- More power amplifiers if initially the power amplifiers is split between unknown sectors.

- Two or more carriers if the operator frequency allocation per units.

- Transmit diversity with a second power amplifier per sector.

The uplink coverage is not affected by these upgrades.

- Capacity Per $\mathrm{km}^{2}$ :

Providing higher capacity is challenging in urbane area (i.e. traffic per $\mathrm{km}^{2}$ can be very high).

For macrocell layer assuming maximum capacity per site per carrier is

3 Mbps with three sectors, the maximum capacity with maximum site density 5 sites $/ \mathrm{km}^{2}$; with three carriers. 
Maximum capacity $=$ number of carrier $\times$ maximum capacity per site

per carrier $\times$ maximum dense site density.

Maximum capacity $=3 \times 3 \times 5=45 \mathrm{Mbps} / \mathrm{km}^{2}$ when capacity in needed but with increased macro site density of e.g. 5 sites $/ \mathrm{km}^{2}$ the maximum site density is $45 \mathrm{Mbps}$.

For microcell layer with 30 site $/ \mathrm{km}^{2}$.

Maximum capacity $=3 \times 2 \times 30=180 \mathrm{Mbps} / \mathrm{km}^{2}$.

\section{- Soft Capacity (Erlarg Capacity)}

The number of channels per cell is calculated for different data rate, as in figure (1). Based on these figures, the maximum traffic density is defined as:

Traffic density $=\frac{\text { Call arrival rate }}{\text { Call departure rate }}$

Where: traffic density is in Erlarg.

Call arrival rate and call departure rate both are in calls / sec.

If the capacity is hard blocked i.e. limited by the amount of hardware, the Erlarg capacity can be obtained from the Erlarg B model [8]. If the maximum capacity is limited by the amount of interference in the air interface it is a soft capacity and there is no single fixed value for the maximum capacity.

Soft capacity is important for high bit rate real time data users (e.g. for video connections). In the soft capacity calculations below, it is assumed that the number of subscribers are the same in all cells, but the connection starts and ends independently. The call arrival interval is a Poisson distribution.

For WCDM soft capacity is defined in equation (15) below as:

$$
\text { Soft Capacity }=\frac{\text { Erlarg Capacity with Soft Blocking }}{\text { Erlarg Capacity with Hard Blocking }}-1
$$

Soft capacity for the uplink can be approximated based on the total interference at the base station. This interference includes both own cell 
and other cell interference. The total channel pool is obtained by multiplying the number of channels per cell for equally loaded case by ( 1 + i) , which gives the single isolated cell capacity [1][8], since:

$$
\mathrm{i}+1=\frac{\text { Other Cell Interference }}{\text { Own Cell Interference }}+1
$$

The basic Erlarg B formula is then applied to the larger channel pool (interference pool).

- The Erlarg capacity obtained is shared between the cells. The soft capacity estimation procedure is as follows:

- Calculating the number of channel per cell (N) (for equally loaded) based on uplink load factor using equation (4).

- Multiplying the number of channel by $(1+i)$ to obtain the total channel pool in the soft blocking case.

- Calculating the maximum offered traffic for the Erlarg B formula.

- Dividing the Erlarg capacity by $(1+i)$ uplink soft capacity calculations:

Using the same values of $E_{b} / N_{o}, W, R$ and $v$ as in paragraph 3.1 for the uplink load factor, assuming equally loaded cells. Also the $3 \mathrm{~dB}$ noise rise corresponds to $\eta_{\mathrm{UL}}=0.5(50 \% \mathrm{kbps}$ load) and $6 \mathrm{~dB}$ noise rise corresponds

0.75 (75\% load) [1].

For $3 \mathrm{~dB}$ noise rise, $\eta_{\mathrm{UL}}=0.5$, using equation 3 ; the number of users $(\mathrm{N})$ is found to be 44.5 .

2. For the value of $\mathrm{N}=44.5$ and blocking probability of 0.02 , the hard blocking probability is 34.5 from Erlarg B tables [6].

3. Trunking efficiency is defined in [1] as:

$$
\begin{aligned}
\text { Trunking efficiency } & =\frac{\text { Hard Blocking Capacity }}{\text { Number of Channels }} \\
& =\frac{35.5}{44.5}=78 \%
\end{aligned}
$$

4. The number of channels per cell $=\mathrm{N}(1+\mathrm{i})=73.5$

5. Soft blocking: Soft blocking is calculated by substituting $N(1+i)$ in Erlarg B table and dividing the $(1+i)$.

6. Soft capacity is calculated using equation (18) below: 


$$
\text { Soft Capacity }=\frac{\text { Soft Blocking }}{(1+\mathrm{i})}=8 \%
$$

Table 6. Soft capacity calculations for the downlink.

\begin{tabular}{|l|l|l|l|l|l|}
\hline $\begin{array}{l}\text { Bit } \\
\text { rate } \\
\text { (kbps) }\end{array}$ & $\begin{array}{l}\text { Channels } \\
\text { per cell } \\
\text { N(1+i) }\end{array}$ & $\begin{array}{l}\text { Hard } \\
\text { blocking } \\
\text { (Erlarg) }\end{array}$ & $\begin{array}{l}\text { Trunking } \\
\text { efficiency }\end{array}$ & $\begin{array}{l}\text { Soft } \\
\text { blocking } \\
\text { (Erlarg) }\end{array}$ & $\begin{array}{l}\text { Soft } \\
\text { capacity }\end{array}$ \\
\hline 12.7 & 74 & 35 & $78 \%$ & 38.1 & $8 \%$ \\
\hline 32 & 40.5 & 17 & $69 \%$ & 5.4 & $14 \%$ \\
\hline 64 & 22 & 7.5 & $56 \%$ & 9 & $20 \%$ \\
\hline 144 & 11.3 & 2.8 & $41 \%$ & 3.6 & $22 \%$ \\
\hline 384 & 4.5 & 0.5 & $18 \%$ & 0.84 & $68 \%$ \\
\hline
\end{tabular}

From table 6, it can be observed that for increased values of bit rate, the number of channels per cell, hard blocking, trucking efficiency, soft blocking their values decreases, while soft capacity increases this is so if the radio resource management can utilize a high capacity in one cell if the adjacent cells have lower loading.

\section{Conclusions:}

The various design parameters have been estimated for different data rates (12.2 kbps to $384 \mathrm{kbps}$ for voice and video application). The essential concluding remarks as:

- The cell range decreases with increasing data rate in urban and suburban areas.

- Noise rise increase with increasing number of users (or throughput).

- For a given number of users (or throughput) the noise rise increase with the interference factor (i).

- Cell loading affect the coverage range in the down link more than the uplink. 
- With increasing bit rate the number of channels per cells, hard blocking, soft blocking, and trucking efficiency all decrease.

- Soft capacity increase with higher bit rate.

\section{References:}

1- Holma, H., Toskala, A., "WVDMA for UMTS"., $3^{\text {rd }}$ Edition, John Wiley \& Sons, 2004.

2- Sipila, K., Laitho-Steffens, J. Jasberg, M. and Wacker, A., "Modeling the Impact of the Fast Power Control on the WCDMA Uplink", Proceedings of VTC 99, Houston, Texas, May 1999, pp. 1266-1270.

3- PahLavan, K., Levesque, A. H., "Wireless Information Network". John Wiley \& Sons, Ins. pp. 74-82, 1995.

4- Walke, B. H., "Mobile Radio Networks", $2^{\text {nd }}$ Edition, John Wiley \& Sons, Inc. 2002, pp. 44-46.

5- Lempiainin, J., Manninen, M., "UMTS Radio Network Planning, Optimisation and QoS Management", Klawer Academic Publisher, 2003.

6- Nawrocki, M. J., Dohler, M., Aghvami, A. H., "Understanding UMTS Radio Network", John Wiley \& Sons, Ltd, 2006, Chapter 10.

7- Wacker, A., Laiho-Steffens, J., Sipila, K., and Heiska, K., "The Impact of the Base Station Sectroisation on WCDMA Radio Network Performance", Proc., of VTC 99, Amsterdam, The Netherlands, September 1999 , pp. 2611-2615.

8- Lee, J., Miller, L., "CDMA System Engineering Handbook", Artech Howe, 1995. 